\title{
Constraints faced by the members of organised and unorganized sector of milk producers in Gujarat
}

\author{
H. Sharma ${ }^{*}$, M.C. Makwana and S.S. Kalamkar
}

Agro Economic Research Centre, SP University, Vallabh Vidyanagar, Gujarat

*Corresponding author E-mail: Sharmah007@gmail.com

Journal of Livestock Science (ISSN online 2277-6214) 12: 23-30

Received on 26/8/20; Accepted on 18/11/2020; published on 3/1/2021

doi. 10.33259/JLivestSci.2021.23-30

\begin{abstract}
Present study conducted to assess the constraint faced by the milk producers in four milk unions/ district were selected from four regions of the Gujarat state, i.e. Mehsana (North Gujarat), Bharuch (South Gujarat), Junagarh (West Gujarat) and Pachmahal (East Gujarat). Four villages were selected from each district. Two villages having dairy cooperative (organised) and two villages without dairy cooperative (unorganised) from each region. Total 120 Milk Producer Selected from Organised sector and 120 milk producers from unorganised sector, the total sample size of milk producers in State were 240. The constraints were ranked by using Garrett's ranking technique. The selected household average size was 5.8 members with average age of respondents of between 44-46 years. Dairy Cooperative Society (DCS) member households recorded the adequate supply of cattle feed which was also made available on credit by cooperative society, however most of households mentioned that cost of cattle feed and miner mixtures was high. Non- Dairy Cooperative Society (NDCS) member households faced other constraints such as lack of marketing facility for dairy business, unavailability of chilling facilities at village level for milk preservation, unavailability of medicine and equipments required for quality milk production. The animal husbandry departments must be rejuvenated to act as drivers of growth for dairy sector. The veterinary literature should be provided in village and Dairy Federation should be provided marketing facilities at village level for the outlet of milk and milk product. The loan sanction procedure should be made easy.
\end{abstract}

Keywords: constraints; dairy; milk producers; Gujarat 


\section{Introduction}

Animal husbandry in India is closely interwoven with agriculture and obviously plays an important role in the national economy and also in the socio-economic development of millions rural households (Vaidyanathan, 1989; Mishra, 1995; Chawla, et al, 2004; Sharma, 2004; Birthal, 2016). Livestock rearing is one of the most important economic activities in the rural areas of the country providing supplementary income for most of the families dependent on agriculture. In many cases, livestock is also a central component of small holder risk management strategies (Randolph et al., 2007). India is endowed with a significant proportion of the world's livestock population (Prabaharan, 2002; Sharma and Sharma, 2002). India stands at first position in terms of cattle and buffalo population in the world. The population of cattle and buffalo in India was 218 million and 115 million in 2012 which accounts for 14.7 per cent and 58 per cent share respectively of world cattle and buffalo population, most of which are milch cows and milch buffaloes (GOI, 2004). This sector provides regular employment to 9.8 million peoples in principal status and 8.6 million people in subsidiary status. More importantly, women constitute 71 percent of the labour force in livestock farming (GOI, 2002). Dairy development in India has been acclaimed as one of the most successful development programmes under the world's largest integrated dairy development programme 'Operation Flood' (Shiyani, 1996; NAAS, 2003). India ranks first in the world ${ }^{1}$ in milk production, which has increased to 187.75 million tonnes in 2019-20 from 17 million tonnes in 1950-51. Nearly 51 per cent of milk production is contributed by buffalo followed by cow $(45 \%)$ and goats $(4 \%)$.

The dairy development in Gujarat indicate that one fourth of the agriculture sector output comes from livestock sector and milk contributes to around 20 per cent to the agricultural GDP of Gujarat and is one of the biggest sectors for supporting livelihood in the state. Gujarat State possesses a remarkable position in the country so far as livestock wealth and development are concerned. The State has high-quality, high-yielding breeds of cattle and buffaloes. Gir and Kankrej breeds in cows, and Mehsani, Jafarbadi and Surti breeds in buffaloes were known for their high milk yielding capacity. The State Government policy has been providing necessary support for dairy development in the state through co-operative sector. Gujarat ranks third among the milk producing states in India, achieving 122.62 lakh MT in 2015-16, which has increased from the 30.9 lakh tonnes during 1983-84. Out of total milk production, about 53.11 per cent of the milk production is contributed by Indigenous Buffaloes followed by 22.94 per cent by indigenous cattle. The crossbreed cattle contribute 21.6 per cent of the total milk production in the state whereas Goat contributes 2.36 per cent to total milk production. The productivity of cows and buffalo in term of daily milk yield is increasing continuously. Despite of increase in milk yield, there is still a wide scope for improving milk yield of milch animals. The highest milk yield was recorded in cross breed cows. However, as against the estimated animals' requirements, feed resources available in Gujarat are lower. The co-operatives have developed modern systems of veterinary care and artificial insemination and provide these services to a large number of milk producers at very low prices. The district cooperatives have vans equipped with a trained veterinary surgeon and medicines stationed in different centres to cater to the needs of the members of the co-operatives. Beside, despite of impressive growth in milk production during the past three decades, productivity of dairy animals continues to remain very low and milk marketing system is primitive (Rajendran and Mohanty, 2004; Sarkar and Ghosh, 2010). Currently, more than 80 per cent of the milk produced in the country is marketed by the unorganised sector (private organisations) and less than 20 per cent is marketed by the organised sector (government or cooperative societies). But, both organised and unorganised sectors in the dairy industry of the country face a lot of constraints. Therefore, it is essential to study the various types of constraints faced by the both cooperative and non-cooperative dairy producers.

\section{Methodology}

Gujarat has varying topographic features though a major part of the state was dominated by parched and dry region. The average rainfall in the state varies widely from $250 \mathrm{~mm}$ to $1500 \mathrm{~mm}$ across various zones. Out of 8 agro-climatic zones, five are arid to semi-arid in nature, while remaining three are dry sub-humid in nature. As per the sampling framework, four milk unions from four regions of the state (Map.1), i.e. Mehsana (North Gujarat), Bharuch (South Gujarat), Junagarh (West Gujarat) and Pachmahal (East Gujarat) were selected for study period 2017-18. Four villages were selected from each district. Two villages having dairy cooperative (organised) and two villages without dairy cooperative (unorganised) from each region. Total numbers of selected villages in the State were 16 villages. From each selected village, 15 milk producers were selected randomly. Total sample size of milk producers in State was 240. For the study, primary data were collected from the selected Milk producers, Primary Dairy Cooperative Societies and Milk Unions through structured and pretested schedules/questionnaires.

${ }^{1}$ Forecast by FAO indicate that the world's milk production in 2016 would be 817 million tonnes, while that of India would be 160.4 million tonnes (NCAER, 2017). 


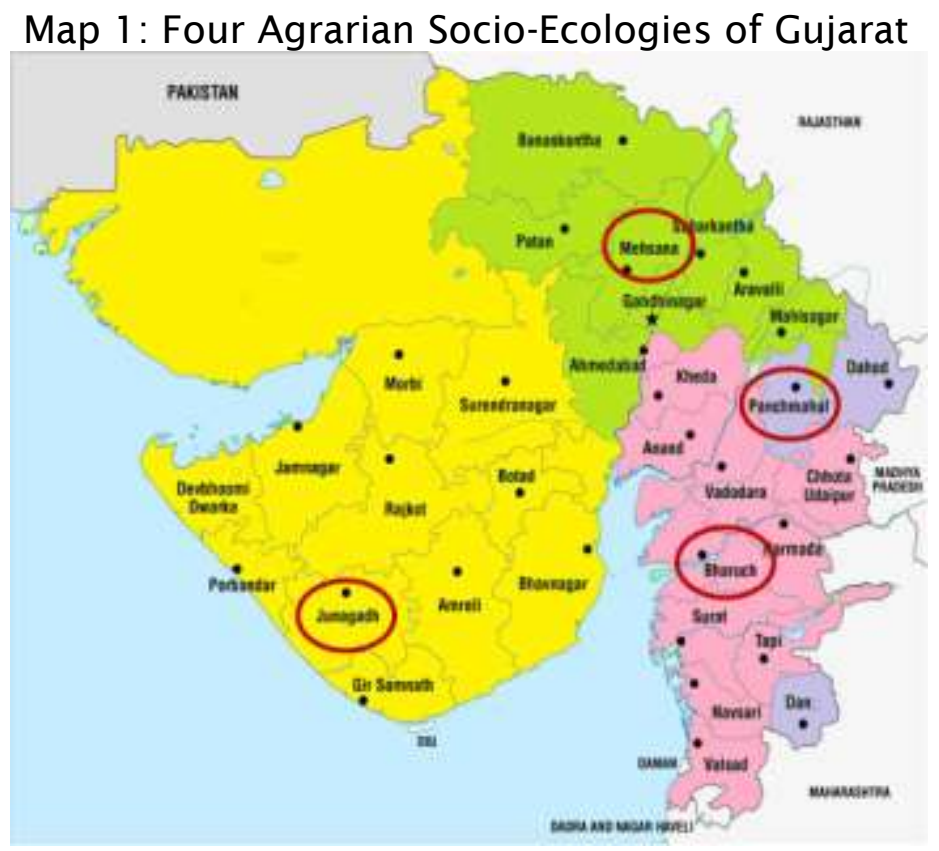

\section{Tool and Technique}

Information regarding the problems faced by milk producers was procured. Constraints were identified in consultation with the experts of milk producer of Organised and unorganised sector and producers were be asked to rank the problems proposed to them. Garrett's Ranking Technique provides the alter of orders of constraints and compensation into numerical scores. Garrett's formula for converting ranks into percent is:

Where,

$$
\text { Percent Position }=100 *(\mathrm{Rij}-0.5) / \mathrm{Nj}
$$

Rij = rank given for ith constraint by jth individual;

$\mathrm{Nj}=$ number of constraint ranked by $\mathrm{jth}$ individual.

The per cent position of each rank will be converted into scores referring to the table given by Garrett (1981).

\section{Result and Discussion}

\section{Socio-Economic Characteristics}

The various socio-economic factors for instance size of family, education and training of dairy producer, availability of land and off farm income, experience in dairy, etc have direct influence on dairy farmers' decision to whether they want to expand and improve their dairy operations. The socio-economic characteristics of selected sample households are presented in Table 1. It can be seen from this table that the selected household average size was 5.8 members which was found almost similar in both categories (DCSmember of dairy cooperative society \& NDCS- non member of dairy cooperative society). The family composition indicates that around 38 percent were male, followed by 35 percent female and remaining were children. Most of the respondents were male. The average age of respondents of both categories was between 44-46 years, which was marginally higher in DCS than NDCS respondents. Also, in case of average family age, it was around 31 years in DCS members while same was 29 years in NDCS dairy producers. The figures on average level of education of family indicate that on an average respondent were educated up to 7 th standard. Around three members from each family engaged in dairy activity.

As dairy business is mostly deal by the females, it was expected that they would the decisions makers. However, field data indicate that about 90 per cent of decisions are taken by the male, while it was mentioned while data collection that female provide the support to the decision taken by the male, as per tradition followed in India everywhere. The distribution of selected DCS households as per social group indicate the dominance of households belongs to other backward class (48\%), followed by General category (30\%), Scheduled Tribe $(18 \%)$ and remaining were from Scheduled Caste (3\%). In case of NDCS households, 46 per cent households belong to other backward classes, 27 per cent were scheduled caste while remaining was scheduled tribe households. The main occupation of the selected households was agriculture comprised of cultivation of land as 
a farmer along with supportive allied activity of animal husbandry and dairying. It was very surprising to note that very few households were engaged as agriculture labour or as a non farm labour. Thus, a number of dairy producers initially became involved in dairy farming as a secondary and supportive activity.

The selected DCS households has 1.8 ha operational land holding, of which 88.9 per cent was irrigated, while same was 1.9 ha in NDCS households with 84 per cent land under irrigation. The selected households in both the group has significant land under irrigation and facility of protective irrigation to save crop in case of less rainfall during kharif or grow more crop during rabi and summer seasons. The DCS households were found more experienced (21.7 years) than NDCS household (19.6 years). Around one third of selected households were below poverty line as per income group category indicates relatively better economic condition of two third households in both groups.

\section{Cropping pattern}

The details on cropping pattern of selected households during 2015-16 are presented in Table 3. It can be seen from the table that out of total gross cropped area, around 53-55 per cent area was in kharif season, around 36 per cent was in rabi season and remaining was in summer season. Groundnut, cotton, soybean, maize, tur and moog were the dominant kharif crops, while wheat and gram were important crops grown in Rabi season while summer bajra and groundnut were grown. Besides, significant area was allotted to fodder crops as well, due to requirement of fodder for dairy animals. The cropping intensity was found higher in case of DCS households than NDCS households.

\section{Constraints faced by Milk Producers \\ Infrastructural Constraints:}

The details on infrastructural constraints faced by the selected household are presented in Table 4. It can be seen from the table that in case of DCS households, the four major infrastructural constraints were Lack of improved equipments given rank First followed by Unavailability of green/ dry fodder throughout the year, Low average milk yield of the milk animals and Lack of training facilities. The underlying causes behind the major infrastructural constraints faced by NDCS were Occasional availability of semen at the AI centre, Unavailability of emergency veterinary services and Lack of training facilities. As comparative to NDCS, the AI and veterinary service easily provided by milk Union to dairy cooperative members. Rathod et al. (2011) also highlighted the non-availability of adequate veterinary services and high cost of medicine as major constraints among health care services.

Table 1: Family Profile of Selected Households

\begin{tabular}{|c|c|c|c|}
\hline $\begin{array}{l}\text { Sr. } \\
\text { No }\end{array}$ & Particulars & $\begin{array}{c}\text { DCS } \\
(\mathrm{n}=120)\end{array}$ & $\begin{array}{c}\text { NDCS } \\
(\mathrm{n}=120)\end{array}$ \\
\hline \multirow[t]{5}{*}{1} & Av. Household Size (Nos.) & & \\
\hline & Male & 2.2 & 2.3 \\
\hline & Female & 2.1 & 2.1 \\
\hline & Children(Below 15 Year) & 1.5 & 1.2 \\
\hline & Total & 5.8 & 5.7 \\
\hline \multirow[t]{3}{*}{2} & Gender of Respondent/HH (\%) & & \\
\hline & Male & 89.2 & 85.8 \\
\hline & Female & 10.8 & 14.2 \\
\hline \multirow[t]{4}{*}{3} & Av. Age of respondent (years) & & \\
\hline & Male & 45.9 & 43.9 \\
\hline & Female & 43.6 & 43.8 \\
\hline & Total & 45.5 & 43.9 \\
\hline 4 & Av. Age of family (years) & 31.1 & 29 \\
\hline 5 & Av. Education of respondent/HH (years) & 6.92 & 7.23 \\
\hline 6 & $\%$ of Family members works in dairy & 58.4 & 56.3 \\
\hline
\end{tabular}

Source: Field survey data. 
Table 2: Socio-economic characteristics of selected households

\begin{tabular}{|c|c|c|c|}
\hline S. N. & Particulars & $\%$ DCS & $\%$ NDCS \\
\hline \multirow[t]{3}{*}{1} & Gender of Decision Maker (\%) & & \\
\hline & Male & 89.20 & 91.70 \\
\hline & Female & 10.80 & 8.30 \\
\hline \multirow[t]{5}{*}{2} & Social Group (\% to total) & & \\
\hline & Scheduled Tribe & 18.30 & 26.70 \\
\hline & Scheduled Caste & 3.30 & 8.30 \\
\hline & Other Backward Class & 48.30 & 45.80 \\
\hline & General/Open & 30.00 & 19.20 \\
\hline \multirow[t]{19}{*}{3} & Occupation (\%) & & \\
\hline & Principal & & \\
\hline & Cultivator & 71.70 & 65.80 \\
\hline & AH \& Dairying & 28.30 & 23.30 \\
\hline & Agri. Labour & 0.00 & 3.30 \\
\hline & Nonfarm Labour & 0.00 & 1.70 \\
\hline & Own Non-Farm Establishment & 0.00 & 0.00 \\
\hline & Trade & 0.00 & 0.00 \\
\hline & Employee in Service & 0.00 & 5.80 \\
\hline & Other (Specify) & 0.00 & 0.00 \\
\hline & Subsidiary & & \\
\hline & Cultivator & 20.00 & 14.20 \\
\hline & AH \& Dairying & 71.70 & 76.70 \\
\hline & Agri. Labour & 5.00 & 1.70 \\
\hline & Nonfarm Labour & 3.30 & 6.70 \\
\hline & Own Non-Farm Establishment & 0.00 & 0.00 \\
\hline & Trade & 0.00 & 0.00 \\
\hline & Employee in Service & 0.00 & 0.80 \\
\hline & Other (Specify) & 0.00 & 0.00 \\
\hline \multirow[t]{4}{*}{4} & Av. Operational land holding (area in ha) & & \\
\hline & Irrigated & 1.60 & 1.60 \\
\hline & Un irrigated & 0.20 & 0.30 \\
\hline & Total & 1.80 & 1.90 \\
\hline 5 & Av. Experience in Dairy (years) & 21.70 & 19.60 \\
\hline \multirow[t]{3}{*}{6} & Income Group (\%) & & \\
\hline & BPL & 33.30 & 37.50 \\
\hline & APL & 66.70 & 62.50 \\
\hline \multirow[t]{4}{*}{7} & House Structure (\%) & & \\
\hline & Pucca & 64.20 & 50.80 \\
\hline & Semi-Pucca & 20.80 & 24.20 \\
\hline & Kuccha & 15.00 & 25.00 \\
\hline
\end{tabular}

Source: Field survey data.

Table 3: Cropping Pattern of Sample Household

\begin{tabular}{|l|l|l|l|l|l|l|c|}
\hline $\begin{array}{l}\text { Sr. } \\
\text { No }\end{array}$ & Season /Crops & $\begin{array}{l}\text { DCS } \\
(\mathrm{n}=120)\end{array}$ & $\begin{array}{l}\text { NDCS } \\
(\mathrm{n}=120)\end{array}$ & $\begin{array}{l}\text { Sr. } \\
\text { No }\end{array}$ & Season /Crops & $\begin{array}{l}\text { DCS } \\
(\mathrm{n}=120)\end{array}$ & $\begin{array}{l}\text { NDCS } \\
(\mathrm{n}=120)\end{array}$ \\
\hline $\mathbf{A}$ & Kharif & & & $\mathbf{B}$ & Rabi & & \\
\hline & Bajra & 0.69 & 2.1 & & Wheat & 23.92 & 22.57 \\
\hline & Jowar & 0.06 & 10.56 & & Maize & 0.64 & 3.32 \\
\hline & Paddy & 2.29 & 2.4 & & Gram & 0.12 & 0.41 \\
\hline & Maize & 5.06 & 2.41 & & R\&M & 9.26 & 6.32 \\
\hline & Tur & 1.29 & 2.63 & & Fodder crops & 5.43 & 1.65 \\
\hline & Moong & 3.77 & 1.23 & & Others & $\mathbf{4 0 . 7}$ & $\mathbf{3 4 . 7 4}$ \\
\hline & Moth & 0.27 & 0.38 & & & & Total Rabi \\
\hline & Castor seed & 1.24 & 2.47 & C & Summer & 0.92 & 1.64 \\
\hline & Groundnut & 11.7 & 5.23 & & Bajra & 0.32 & 2.4 \\
\hline & Soyabean & 9.63 & 13.14 & & Jowar & 0.79 & 1.59 \\
\hline & Cotton & 1.12 & 7.52 & & Moong & 0.18 & 0 \\
\hline & Sugarcane & 4.3 & 0.62 & & Groundnut & 9.72 & 3.41 \\
\hline & Fodder Crops & 4.27 & 4.07 & & Guar seed & $\mathbf{1 3 . 2 3}$ & $\mathbf{9 . 7 9}$ \\
\hline & Others & 0.38 & 0.68 & & Fodder crops & $\mathbf{1 8 2 . 4}$ & $\mathbf{1 8 0 . 2 9}$ \\
\hline
\end{tabular}


Table 4: Constraints Faced by DCS and NDCS Sample Household

\begin{tabular}{|c|c|c|c|c|}
\hline S.N. & DCS Households & G.S. & NDCS Household & G.S. \\
\hline $\mathrm{A}$ & Infrastructural Constraint & $(\%)$ & & $(\%)$ \\
\hline 1 & Lack of improved equipments & 61.02 & Occasional availability of semen at the AI centre & 64.41 \\
\hline 2 & Unavailability of green/ dry fodder throughout the year & 59.03 & Unavailability of emergency veterinary services & 59.39 \\
\hline 3 & Low average milk yield of the milk animals & 52.62 & Lack of training facilities & 56.3 \\
\hline 4 & Lack of training facilities & 52.6 & Lack of improved equipments & 51.55 \\
\hline 5 & Unavailability of cattle feed and fodder seed on credit & 48.78 & Unavailability of vaccines & 49.83 \\
\hline 6 & Unavailability of vaccines & 48.26 & Irregular \& inadequate supply of cattle feed & 49.3 \\
\hline 7 & Infrequent visit of veterinary staff & 47.35 & $\begin{array}{l}\text { Unavailability of green/ dry fodder throughout } \\
\text { the year }\end{array}$ & 48.4 \\
\hline 8 & Unavailability of emergency veterinary services & 46.43 & $\begin{array}{l}\text { Unavailability of cattle feed and fodder seed on } \\
\text { credit }\end{array}$ & 45.24 \\
\hline 9 & Irregular \& inadequate supply of cattle feed & 46.14 & Infrequent visit of veterinary staff & 45.08 \\
\hline 10 & $\begin{array}{l}\text { Unsuitability of the time of delivery of milk during winters } \\
\text { due to bitter cold in early hours of the day }\end{array}$ & 45.2 & Low average milk yield of the milk animals & 43.58 \\
\hline 11 & Occasional availability of semen at the AI centre & 40.58 & $\begin{array}{l}\text { Unsuitability of the time of delivery of milk } \\
\text { during winters due to bitter cold in early hours } \\
\text { of the day }\end{array}$ & 34.93 \\
\hline $\mathrm{B}$ & \multicolumn{4}{|l|}{ Economic Constraints } \\
\hline 1 & Low price of milk offered & 64.45 & High cost of veterinary medicines & 65.38 \\
\hline 2 & High cost of cattle feed and mineral mixture & 63.45 & High cost of fodder seed & 63.38 \\
\hline 3 & High cost of veterinary medicines & 54.13 & Low price of milk offered & 63.38 \\
\hline 4 & High cost of fodder seed & 52.93 & High charges of emergency veterinary services & 58.33 \\
\hline 5 & High cost of crossbreed cow & 49.74 & High cost of cattle feed and mineral mixture & 57.8 \\
\hline 6 & Delay in payment of milk & 47.82 & Delay in payment of milk & 53.53 \\
\hline 7 & $\begin{array}{l}\text { Low provision of loan in society or govt. for purchasing } \\
\text { cattle }\end{array}$ & 45.03 & High cost of crossbreed cow & 52.96 \\
\hline 8 & High charges of emergency veterinary services & 44.58 & $\begin{array}{l}\text { Low provision of loan in society or govt. for } \\
\text { purchasing cattle }\end{array}$ & 48.96 \\
\hline 9 & Low incentives or bonus for supplying milk & 42.93 & Low incentives or bonus for supplying milk & 46.9 \\
\hline 10 & High charges for insurance & 34.94 & High charges for insurance & 44.39 \\
\hline $\mathrm{C}$ & \multicolumn{4}{|l|}{ Marketing Constraints } \\
\hline 1 & Less knowledge about marketing strategies & 59.48 & Less knowledge about marketing strategies & 60.44 \\
\hline 2 & Low risk taking behaviour & 54.39 & Lack of time for marketing & 54.88 \\
\hline 3 & Lack of time for marketing & 53.5 & $\begin{array}{l}\text { No or less advance payment for milk by } \\
\text { society/vendors }\end{array}$ & 50.12 \\
\hline 4 & No or less advance payment for milk by society/vendors & 49.96 & Low risk taking behaviour & 48.5 \\
\hline 5 & Irregular sell of milk & 41.6 & Irregular sell of milk & 46.52 \\
\hline 6 & Inability to market for value added products & 41.08 & Inability to market for value added products & 39.55 \\
\hline $\mathrm{D}$ & \multicolumn{4}{|l|}{ Technical Constraints } \\
\hline 1 & $\begin{array}{l}\text { Lack of knowledge about cheap \& scientific housing of } \\
\text { animal }\end{array}$ & 59.1 & Lack of technical guidance & 62.18 \\
\hline 2 & Unavailability of high genetic merit bull & 54.88 & Poor knowledge about feeding and health care & 52.31 \\
\hline 3 & Lack of technical guidance & 46.1 & $\begin{array}{l}\text { Poor conception rate through artificial } \\
\text { insemination }\end{array}$ & 45.68 \\
\hline 4 & Poor conception rate through artificial insemination & 44.82 & $\begin{array}{l}\text { Lack of knowledge about cheap \& scientific } \\
\text { housing of animal }\end{array}$ & 45.27 \\
\hline 5 & Poor knowledge about feeding and health care & 44.1 & Unavailability of high genetic merit bull & 43.58 \\
\hline $\mathrm{E}$ & \multicolumn{4}{|l|}{ Socio-Psychological Constraints } \\
\hline 1 & Lack of purchasing power & 59.78 & Lack of purchasing power & 65.46 \\
\hline 2 & Lack of time due to busy in domestic /agricultural work & 52.75 & Lower socioeconomic conditions & 55.23 \\
\hline 3 & Lower socioeconomic conditions & 49.74 & $\begin{array}{l}\text { Lack of time due to busy in domestic } \\
\text { /agricultural work }\end{array}$ & 52.58 \\
\hline 4 & Milk of crossbred cow has poor acceptability & 49.02 & $\begin{array}{l}\text { Lack of cooperation and coordination among } \\
\text { members }\end{array}$ & 46.35 \\
\hline 5 & Milk producers are meant for influential people & 45.74 & Milk producers are meant for influential people & 46.09 \\
\hline 6 & Lack of cooperation and coordination among members & 43.01 & Milk of crossbred cow has poor acceptability & 34.29 \\
\hline
\end{tabular}

G.S.- Garrett's Score

\section{Economic Constraints}

The details on economic constraints faced by the selected household are presented in Table 4. It can be seen from the table that in case of DCS households, the four major economic constraints were low price of milk offered, ranked first. Maity and Sidhu (2001) and Jayalaxami et al. (1997) also reported low price of milk as a major constraint. Radder and Bhanj (2011) also pointed that majority of the farmers are not satisfied with the price they were getting for the milk produce, which affects the quality. The second rank to high cost of cattle feed and mineral Mixture, High cost of veterinary medicines and high cost of fodder seed. The underlying causes behind the major economic constraints faced by NDCS were high cost of veterinary services, high 
charges of emergency veterinary services, high cost of cattle feed and mineral mixtures, low price of milk offered, high cost of fodder seed.

\section{Marketing Constraints}

The details on marketing constraints faced by the selected household are presented in Table 4 . It can be seen from the table the two main marketing constraints faced by the DCS households were less knowledge about marketing strategies and low risk taking behaviour. The NDCS households has faced four marketing constraints viz., less knowledge about marketing strategies, no or less advance payment for milk by society/vendors, lack of time for marketing and low risk taking behaviour.

\section{Technical Constraints}

The details on technical constraints faced by the selected household are presented in Table 4. It can be seen from the table the two main technical constraints faced by the DCS households were Lack of purchasing power and Lack of time due to busy in domestic /agricultural work because most of DCS are small and Marginal farmers. The NDCS households has faced four technical constraints viz., less knowledge about marketing strategies, no or less advance payment for milk by society/vendors, lack of time for marketing and low risk taking behaviour. Same finding supporting the present work are studies of Kumar et al. (2011) who recorded that poor knowledge about clean milk production (72\%), poor housing to dairy animals $(69.33 \%)$, inadequate knowledge about proper feeding of milch animals $(81.33 \%)$ and lack of dairy cooperatives $(78.66 \%)$ are the major constraints of dairy development.

\section{Socio-Psychological Constraints}

The details on socio-psychological constraints faced by the selected household are presented in Table 4. It can be seen from the table the two main socio-psychological constraints reported by DCS as well as NDCS households were lack of purchasing power and lower socio-economic conditions. Lack of time due to busy in domestic/agricultural work was another problems faced by them.

\section{Conclusion}

The performance of the dairy sector in depends on many factors includes input supply (particularly feed) and service provision (veterinary service and Artificial Insemination (AI) or breed) or output services. DCS households recorded the adequate supply of cattle feed and emergency veterinary services while NDCS households did not have facility to get any support from the dairy cooperatives existing in their area, they are fully depend on the agent or private agency to get support for input and output service systems.

\section{Policy Recommendation}

a) The co-operative structure is very weak in Saurashtra and Kutch regions of the state. Therefore, presence of Milk Producer Company's sales \& distribution network is spread across Saurashtra \& Kutch region support the dairy development in this regions. Therefore, there is a need to support the MPCs in all the areas for balanced development of dairy sector.

b) Non availability of veterinary services at the village level in time is the major constraints. The animal husbandry departments must be rejuvenated to act as drivers of growth for dairy sector. The veterinary literature should be provided in village and Dairy Federation should be provided marketing facilities at village level for the outlet of milk and milk product. The loan sanction procedure should be made easy and loan amount for the purchase of dairy animals need to be increased; need to improve service deliver, enhance the milk price for producers, and technical knowledge for management of dairy enterprise.

\section{References}

1) Birthal, Pratap S. (2016). Innovations in Marketing of Livestock Products in India. Indian Journal of Agricultural Marketing, Vol. 30, No. 3, September December, pp.88-107.

2) Chawla, N.K, Kurup M.P.G. and Sharma V.P. (2004). State of the Indian Farmer- Animal Husbandry, Vol. No. 12, Department of Agriculture and Co-operation, ministry of Agriculture, Government of India, New Delhi.

3) Garrett, H.E. 1981. Statistics in Psychology and education. Vakils, Feffer and Simons Pvt. Ltd., Bombay, India.

4) GOI (2002), Report of the Working Group on Animal Husbandry and Dairying for the Xth Plan (2002-2007), Planning Commission, Government of India.

5) GOI (2004). India 2004, Ministry of Information \& Broadcasting, Govt. of India.

6) Jayalaxmi, G., Shailaja, S. and Sobhana, G. (1997). Constraints experienced by women entrepreneurs. J. Ext. Edu. 8: 1752- 1754.

7) Kumar J, Kumar B and Kumar S (2011). Constraints perceived by farmers in adopting scientific dairy farming practices in Madhuni district of Bihar. Research Journal of Agricultural Sciences, 2: 142- 145. 
8) Maity, M. and Sidhu, D.S. (2001). Adoption of clean milk production and health care practices -A study among dairy farm women. Journal of Dairying Foods Home Science. 20: 232-234.

9) Mishra, S.N. (1995). India's Livestock Economy: A Perspective on Research. Indian Journal of Agricultural Economics, 50(3): 255-263.

10) NAAS (2003). Export Potential of Dairy Products, Policy Paper 23, National Academy of Agricultural Sciences, India, December.

11) Prabaharan, R. (2002). Livestock Development in India- Some Constraints. Agricultural Economics Research Review, pp.13-23.

12) Radder SK and Bhanj SK (2011). Perceptions of dairy farmers of Gadag district in northwestern part of Karnataka state, India regarding clean milk production. Veterinary World, 4: 79-81.

13) Rajendran, K. and Mohanty S. (2004). Dairy Cooperatives and Milk Marketing in India: Constraints and Opportunities, Journal of Food Distribution Research, 35(2): 34-41.

14) Randolph T.F., Schelling E., Grace D., Nocholson C.F., Leroy J.K., Cole D.C., Demment M.W., Omore A., Zinsstag J., Rule M. (2007), "Role of Livestock in human Nutrition and Health for Poverty Reduction in Developing Countries", Journal of Animal Sciences, 85: 2788-2800.

15) Rathod, P.K., Landge, S., Nikam, T.R. and Vajreshwari, S. (2011). Socio-personal profile and constraints of dairy farmers. Karnataka Journal of Agricultural Science 24: 619-621.

16) Sarkar, D. and Ghosh B.K. (2010), "Constraints of Milk Production: A Study on Cooperative and Noncooperative Dairy Farmers in West Bengal”, Agricultural Economics Research Review, 23: 303-314.

17) Sharma, V.P. and Sharma P. (2002). Trade Liberalisation and Indian Dairy Industry, Oxford and IBH Publishing Co. Pvt. Ltd., New Delhi.

18) Shiyani, R.L. (1996). An Economic Inquiry into the Impact of Dairy Co-operatives on Milk Production, Indian Journal of Agricultural Economics 51(3): 396-406. 